\title{
UMA ANÁLISE EXISTENCIALISTA PARA UM CASO CLÍNICO DE TRANSTORNO OBSESSIVO COMPULSIVO ${ }^{1}$
}

\author{
An Existential Analysis for a Case of Obssessive Compulsive Disorder \\ El análisis existencial para un caso deTrastorno obsesivo-compulsivo
}

Sylvia Mara Pires de Freitas

\begin{abstract}
Resumo: O presente relato de experiência se refere ao desvelamento do Projeto de Ser de uma mulher de 35 anos, que apresenta um quadro de Transtorno Obsessivo Compulsivo (TOC), experienciado pela mesma como um evento ahistórico, singular, desconectado de uma possível construção com o social, e entendendo-o como de sua única responsabilidade. Sendo histórico, dialético e social, o homem sartreano deve ser compreendido em toda trama de sua existência, assim, os pensamentos obsessivos e os comportamentos compulsivos, apresentados pela cliente, apesar de poderem ser identificados tais como descritos no DMS IV, anunciam uma existência inundada pela vivência contraditória entre o Ser-para-si e o Ser-para-o-outro. A estrutura deste relato busca seguir a metodologia para a compreensão terapêutica do Projeto de Ser da cliente, segundo a Psicologia Clínica de base sartreana, a qual engendra o caminho de conscientização sobre os fundamentos e nexos das ações do sujeito, favorecendo reflexões sobre os fatores que constituem seu Projeto de Ser, e assim sua apropriação pelo mesmo.
\end{abstract}

Palavras-chave: Psicoterapia existencialista; Transtorno obsessivo compulsivo; Projeto de ser.

Abstract: This experience report provides readers the unveiling of Project Being a woman of 35 years, which presents a nosological of Obsessive Compulsive Disorder (Ocd), experienced the same event as an ahistorical, singular, disconnected from a possible construction with the social, and understanding it as your sole responsibility. As historical, dialectical and social Sartrean man must be understood in any plot of his existence, so the obsessive thoughts and compulsive behaviors presented by the client, although they can be identified as described in the DMS IV, announce a flooded existence the contradictory experience of Being-for-itself and Being-for-the-other. The structure of this report seeks to follow the methodology for the design of therapeutic understanding of Being customer, according to the Clinical Psychology of Sartre's base, which generates the path of awareness about the foundations and links the actions of the subject, encouraging reflection on the factors that Project constitute its being, and thus its appropriation for the same.

Keywords: Existential psychotherapy; Obsessive compulsive disorder; Project self.

Resumen: Este informe proporciona a los lectores la experiencia con la presentación del Proyecto Ser una mujer de 35 años, que presenta una nosológica del trastorno obsesivo compulsivo (Toc), experimentó el mismo evento como un singular ahistórica, desconectado de una posible construcción con lo social, y la comprensión como de su exclusiva responsabilidad. Como histórico, el hombre sartreano dialéctico y social debe ser entendida en cualquier parcela de su existencia, por lo que los pensamientos obsesivos y comportamientos compulsivos presentada por el cliente, aunque se pueden identificar como se describe en el IV DMS, anunciar una existencia inundado la experiencia contradictoria del ser-para-sí y el ser-para-el-otro. La estructura de este informe trata de seguir la metodología para el diseño de la comprensión terapéutica de ser cliente, de acuerdo con la Psicología Clínica de la base de Sartre, que genera el camino de la conciencia acerca de los fundamentos y los enlaces de las acciones del sujeto, fomentando la reflexión sobre los factores que proyecto constituye su ser, y por lo tanto su apropiación para el mismo.

Palabras-clave: La psicoterapia existencial; Trastorno obsesivo-compulsivo; Proyecto libre.

\section{Introdução}

Apesar de o título deste artigo colocar em relevo uma nomenclatura referente a um quadro nosológico (DSM IV e CID-10), a análise compreensiva do caso clínico não se fecha nos sintomas que configuram o Transtorno Obsessivo Compulsivo (TOC). Esta nomenclatura serve

\footnotetext{
Palestra proferida na mesa redonda do I Congresso Sul-Brasileiro de Fenomenologia \& I Congresso de Estudos Fenomenológicos do Paraná, realizado na Universidade Federal do Paraná (UFPR), em Curitiba, de 04 a 07 de junho de 2011.
}

mais como uma provocação para mostrar como é fácil reduzirmos nosso olhar à existência de uma pessoa, por meio de uma classificação diagnóstica.

Em nosso empreendimento, o sujeito será compreendido em sua totalidade, sendo a unidade nosológica integrada a toda dimensão da existência deste, que também se constitui pelo quadro sadio. A análise terá como base a Psicanálise Existencial sartreana, tal como propõe Schneider (2002; 2011).

O destaque dado ao quadro nosológico, objetivou também evidenciar o momento em que a cliente procurou a 
terapia. Schneider (2011, p. 190) coloca, tendo como base o argumento de Jaspers (1979), que:

[...] a questão psicopatológica fundamental é o desenvolvimento de uma personalidade, horizonte em que ela deve ser compreendida. Pode ocorrer que certa sintomatologia, a princípio específica, vá aos poucos se apoderando da existência inteira e acorrentando a personalidade.

Sendo assim, ao encontrar-me com Sol${ }^{2}$ pela primeira vez, percebi sua existência inundada pelos pensamentos obsessivos e ações compulsivas, mas apesar deste destaque, também mostrava questionamentos que denunciavam senso crítico sobre sua situação.

Os pensamentos obsessivos e os comportamentos compulsivos, como todos os outros atos do sujeito, devem ser visados em suas finalidades e não como uma soma de manifestações. Em cada ato há o fundamento da inteireza do sujeito. Conhecendo como transcende a tensão entre mundo concreto e o simbólico, uma vez que homem e mundo se dialogam fazendo-se mutuamente, é que podemos chegar a seu projeto fundamental. Em cada síntese sua história singular e a da humanidade são construídas.

É pelo método sartreano que proponho compartilhar com o leitor mais uma maneira de investigar, compreender e elucidar o mundo de uma pessoa cujo projeto de ser foi construído sob os fundamentos das relações dualistas entre o certo e errado e do perfeito e imperfeito. E na vivência do conflito entre o que deve ser e o que é, mostra algumas ações impregnadas pela preocupação com a necessidade de convencer-se de que seu Ser corresponde ao ideal imposto na infância e, diante a experiência duvidosa sobre a veracidade do mesmo, compele-se a agir de maneira a aliviar a angústia da possibilidade de não Ser, com isso desenvolve comportamentos identificados como Transtorno Obsessivo Compulsivo (TOC).

Entre o Ser conforme os modelos apreendidos e o que é, o sujeito se perde na contradição contida nas informações interiorizadas: deve ser não sendo o que é. Não conseguindo ser o que não é, confirma o ser não perfeito, mas experiencia essa vivência sob o manto da culpa.

Para melhor compreender a metodologia utilizada para a realização da análise do caso em questão, situarei brevemente o método sartreano para investigação da realidade humana, como já coloquei anteriormente, conforme elucidado por Schneider (2002; 2011).

2 Por questão ética, referir-me-ei a cliente por este pseudônimo.

\section{Em Busca da Compreensão do Projeto de Ser}

O projeto de Sartre (1943/1999; 1960/2002), no desvelamento do empreendimento humano, transcendeu os três principais pensadores que deram base para sua teoria: (1) O Eu transcendente de Husserl (1901/1988) perde o sentido, haja vista que para Sartre, a consciência é "desprovida de conteúdos formais e materiais” (Cahet, 2008, p. 04), inclusive de um Eu. Sendo este constituído pelo ato reflexivo, o Eu sartreano reside no mundo, logo é um Eu transcendido. Somente pela consciência da sua criação de seu Eu, na relação com o mundo, que o homem pode assumir a responsabilidade pelas suas escolhas, pelo seu Projeto de Ser; (2) a busca pela compreensão do Ser ontológico heideggeriano, para Sartre deve ser focada no Para-si e suas condutas, construído pela relação dialética entre subjetividade e objetividade e; (3) na proposta marxista de conhecer o homem concreto que transforma o mundo. Sartre ao invés de "[...] descrever a realidade a partir de categorias universais (economia, modo de produção, classe social)” (Schneider, 2002, p. 118), resgata o indivíduo na relação com o coletivo. A concretude da existência individual e social se dá, para Sartre, através da interdependência do diálogo entre ambos.

Através dessas e outras superações, o homem sartreano possui características de um Ser histórico, dialético e também social, visto que a singularidade não se opõe à coletividade e vice versa. Cada ato do sujeito circunscreve os contextos familiar, social, cultural, econômico, político, intelectual, bem como a história da humanidade é construída através de cada escolha singular que tece com todas as outras a trama do universal. Assim, através de sua antropologia podemos compreender a práxis que tem em seu bojo a conversão do processo existencial e do histórico.

Quiçá, por uma concepção dicotomizada do indivíduo e do coletivo, corroborada também pelas teorias sociais que se opõem a concepção de indivíduo das teorias psicológicas, por sua vez construídas sob a influência da atmosfera liberalista e neoliberalista, é que ainda esbarramos na incompreensão do Ser dialético. Mas mesmo assim, realizando uma leitura dialética, neste próprio movimento de oposição, a verdade construída por uma parte dependeu da verdade já construída historicamente pela outra, como ponto de referência para a refutação.

Ao descartarmos a compreensão dialética, negamos o diálogo entre o homem e o mundo, bem como contribuímos com o impedimento de uma das atitudes, que podemos considerar como um dos pilares da teoria sartreana: o assumir a responsabilidade por nossas escolhas.

Sendo a consciência sempre intencional (de e para alguma coisa), todos os nossos atos são livres, solitários e a nós cabe responder por eles. A liberdade de nossas escolhas e consequentes ações nelas fundamentadas, 
[...] por mais alienada que seja[m], sempre transforma[m] o mundo. Isto porque o que caracteriza o homem é a sua transcendência, pois ele 'sempre faz alguma coisa daquilo que fizeram dele', mesmo que ele não se reconheça na sua ação. Ainda que alienados, somos sujeitos de nossa história. Essa transcendência, que faz o sujeito ir além daquilo que lhe é determinado pela materialidade, pela sociedade, é o que Sartre denomina de projeto [grifos da autora] (Schneider, 2002, p. 120).

Resumindo: as verdades são os projetos singulares/ universais construídas no percurso histórico da humanidade, através das relações dialéticas estabelecidas entre indivíduo/mundo, indivíduo/coletividade, subjetividade/ objetividade. São criadas a partir da liberdade da ação individual que, ao se apropriar das diversas verdades objetivas do mundo, escolhe assimila-las, sufocar-se nelas ou rejeita-las (Schneider, 2002).

Para compreender o projeto de Ser de uma pessoa, temos que considerar as condições reais que circundam sua existência concreta, situada e definida durante toda sua história, através de contextos objetivos que podem oferecer-lhe possibilidades e limitações. Por sua vez, os obstáculos e facilidades, também assim serão significados de acordo com o projeto de Ser.

Sartre (1960/2002) propõe o método progressivo-regressivo para se realizar a compreensão do projeto de Ser de uma pessoa. Um método heurístico que permite, progressivamente, nos aproximar da história do sujeito. Partindo de suas experiências, tomamos uma atitude compreensiva para perceber o sentido dado por ele a cada um de seus atos. Comparando as unidades de sentido entre estes, chegamos ao seu projeto fundamental.

Tal método se faz importante, já que:

[...] o homem deve ser encontrado inteiro em todas as suas manifestações. O modo de vida, os trajes, a postura política e moral, a fala, etc, remetem sempre ao projeto do indivíduo, que, como vimos, é fruto das condições materiais, sociais históricas em que ele está inscrito (objetivo) e da sua apropriação ativa por parte do sujeito (subjetivo). A compreensão da realidade humana passa, portanto, pelo movimento dialético de compreensão entre o objetivo e o subjetivo (Schneider, 2002, p. 121).

Diante o exposto, os diagnósticos psiquiátricos tradicionais recortam a existência do indivíduo. Sendo definidos a partir de alguns comportamentos que expressam a leitura da média abstraída de um coletivo, desconsidera a minoria excluída dessa média, bem como a singularidade no diálogo com o mesmo. Reduzir ao diagnóstico a compreensão do projeto de Ser, é desconsiderar a construção dialética, histórica e social do sujeito. É restringir o processo existencial, tornando-o estanque. Mesmo que o diagnóstico nos seja útil para entendermos alguns comportamentos à luz da teoria, ele (diagnóstico) por si, nunca refletirá o sentido dado pelo sujeito à sua existência.

Buscarei a seguir, apresentar a biografia de Sol, uma vez que, segundo Schneider, as biografias possibilitam

[...] a compreensão rigorosa do ser dos seus biografados, [...] devem expor um homem enquanto totalizações, e não como um conjunto fragmentário de comportamentos, emoções, desejos [...], colocam o sujeito concreto, através de um movimento de compreensão, no qual busca esclarecer as condições epocais, culturais, sociais, familiares, além das subjetivas, psicológicas, que possibilitam a seu biografado chegar a ser quem ele foi e como chegou a sê-lo, não abrindo mão do movimento, constante da análise empreendida, entre sujeito e a objetividade, movimento dialético este produtor do psíquico [grifos da autora] (Schneider, 2011, pp. 234-235).

Sendo assim, estruturada de acordo com o objetivo da Psicanálise Existencial sartreana, através da biografia de Sol, buscarei mostrar "o nexo existente entre os diversos comportamentos, gostos, gestos, emoções, raciocínio do sujeito concreto, ao extrair o significado que salta de cada um desses aspectos em direção a um fim” (Schneider, 2011, p. 233). Para tal feito, é necessário lançar mão do método comparativo ao buscar os nexos existentes entre esses aspectos de um indivíduo em situação e com o método compreensivo ou sintético chegar "à intuição do psíquico, atingida por dentro” (Jaspers, 1979 apud Schneider, 2011, p. 234), e assim elucidar o Projeto fundamental que dá sentido ao conjunto.

No entanto, por uma questão didática, apresentarei a biografia, num primeiro momento, descrita "por fora" (ibdem, p. 235), de maneira narrativa, para depois apresentála através de uma análise compreensiva da relação dialética que Sol trava com a objetividade, tal como proposto por Sartre (1997) em sua Psicanálise Existencial.

\section{Apresentando (estaticamente) Sol}

Sol é uma mulher de 35 anos, casada há quatro, com nível superior, sem filhos. Mostra investimento em sua aparência. É uma mulher cuidadosa com seu corpo, aparentando menos idade do que tem. Usa roupas e acessórios descontraídos que acompanham a moda. Trabalha em uma lanchonete como vendedora.

Filha do meio de uma família católica praticante, classe média alta. Os pais estão aposentados. Todos os irmãos, o marido e o pai possuem nível superior. O pai sempre supriu financeiramente as necessidades e desejos da família. Apóia a educação dos filhos em uma moral tradicional. Morou longe dos pais enquanto fez faculdade e depois que se casou. 


\section{$1^{\circ}$ Momento: Demarcando o fenômeno (o Psicodiag- nóstico)}

Neste instante, buscaremos delimitar o fenômeno de acordo com a sua atualidade, uma vez que, de acordo com Schneider (2011, p. 270), "no caso da clínica, a definição clara da sintomatologia e do quadro psicopatológico do paciente, ou seja, a elaboração do psicodiagnóstico [...] é que definirá os rumos da intervenção”.

\section{Na Primeira Sessão}

Esta ocorreu em dezembro de 2010. Sol relatou que há dois anos começou a ter pensamentos constantes de que poderia fazer mal às pessoas e de que poderia contaminar os objetos. Após conversar com alguém, ou mesmo, somente ao olhá-las, se angustiava por pensar que poderia ter falado ou feito alguma coisa que lhe causasse algum mal. Diante este tipo de pensamento obsessivo, tirava a dúvida com marido ou, se possível com a própria pessoa, mas "não sossegava enquanto não perguntava a alguém sobre as consequências de suas ações”.

Quanto aos pensamentos de possível contaminação, como trabalha lidando com comida, lavava constantemente as mãos, abria a torneira com o braço e tocava na tampa do lixo somente com luvas "para não contaminar os objetos e a comida”, e assim poder prejudicar alguém. A preocupação obsessiva com o ter feito alguma coisa errada, também se dava, por exemplo, em ter colocado alguma coisa na comida que servia.

Além destes comportamentos, também pensava que poderia ter deixado alguma coisa ligada, acessa ou aberta em casa e no trabalho, fazendo diversas vezes o ritual de verificação.

Por isso, sua vida social estava muito pobre, tinha medo de sair porque "no dia seguinte fica pensando no mal que pode ter feito a alguém”. Alegou apresentar muito sono, dormindo quando "não tinha que realizar suas obrigações”. Neste momento mencionou que achava estar com Transtorno do Pânico, justificando seu suposto diagnóstico devido a sua ansiedade e ao medo de sair de casa.

Relatou que tinha uma coisa ruim dentro de si (colocando a mão no peito), que "queria arrancar isso", não sabendo definir o que era. Intuí que Sol estava falando da vivência da angústia, mas pensei também que, como nunca deve ter se permitido refletir sobre tal vivência, desconhecia do que se tratava.

Queixou-se que depois que casou o dinheiro ficou escasso, limitando suas possibilidades. Sente-se sozinha quando está em casa, pois está longe da família, o marido trabalha e estuda o dia todo.

3 Optei por intercalar o texto com falas da cliente, para melhor compreensão de suas vivências.
Devido aos comportamentos obsessivo-compulsivos, identificados como clássicos de quem apresenta TOC, segundo sua descrição dos mesmos e, principalmente porque percebi a dificuldade de escuta devido sua ansiedade, solicitei que procurasse um médico homeopata de minha confiança que, por ser flexível em sua atuação profissional, poderia diagnosticar a necessidade de intervenção medicamentosa e o tipo (alopático ou homeopático) e/ou de outro tipo de encaminhamento médico. Este, após consultar Sol, prescreveu Lexapro ${ }^{4}$, iniciando, em janeiro de 2011, com um comprimido ao dia.

\section{Em Algumas Sessões Seguintes: Contando Sua His- tória...}

\section{A Infância}

Ao solicitar-lhe para contar sua história, desde sua infância, Sol a inicia lembrando de uma fala de sua mãe:

"[...] ela disse que quando eu era bebê, chorava muito. Por não saberem o motivo, meus pais me levavam aos médicos e benzedeiras, mas nenhum conseguiu encontrar uma explicação. Eu não ficava com outra pessoa sem ser eles. Diante essa experiência, minha mãe dizia que Deus a livrasse de ter outro filho. Isso me faz sentir uma pessoa problemática para meus pais, como um patinho feio da família”.

Quando terminou a licença maternidade, a mãe retornou ao seu trabalho. O pai trabalhava durante o dia e fazia faculdade no período noturno, em uma cidade próxima, ficando Sol e seu irmão aos cuidados de uma empregada "que gostava muito. Era como uma segunda mãe, pois cuidava da gente e morava também conosco". Nos finais de semana "adorava ir dormir na casa da empregada e dos meus avós paternos, mesmo sabendo que tinha a oportunidade de ficar com meus pais".

Quando começou ir à escola, chorava muito. O pai tinha que ficar com ela esperando que entrasse. Disse não gostar muito de estudar e "não entender porque chorava".

No que tange às brincadeiras, preferia brincar na rua, subir nas árvores, dançar "em cima da mesa". Não gostava de brincar com bonecas, ou de qualquer brincadeira "monótona". Preferia aquelas que lhe fizessem "sentir-se em liberdade. Nunca fui uma pessoa caseira, desde pequena adorava liberdade". Gostava também de nadar, de andar de carrinho de rolimã. Brincava mais com seu

4 ESCITALOPRAM (antidepressivo da classe dos inibidores de serotonina. Indicado para tratamento e prevenção de recaídas ou recorrência da depressão, TP, com ou sem agorafobia, Transtorno de Ansiedade Generalizada, Transtorno Obsessivo Compulsivo e Fobia social). Outros nomes comerciais: Cipralex e Exodus. 
irmão do que com a irmã. Considera que esta era protegida pelo pai. "Hoje dizem que sou muito ciumenta, mas não tive a proteção dele. Tudo que faço, para eles é errado, isso me frustra muito...".

Com relação às tarefas que exigiam maior disciplina: estudou piano até os seis anos, fez pintura em pano e estudou balé durante dois anos, pois "minha mãe era contra eu fazer balé, em função dos gastos que se tinha com as festividades no final do ano".

Em suas relações de amizade, nunca foi de ter muitos amigos, preferindo brincar mais sozinha. Mencionou que em brincadeiras em grupos, sempre tinha um "líder que queria ser o melhor, isso me irritava muito! Eu era muito briguenta e tinha dificuldade em ceder. Dois bicudos não se beijam”. Os pais a comparavam com o irmão que tinha muitos amigos. Quando ia para festinhas em casa de amigos, sentia-se o "patinho feio", pois ninguém a tirava para dançar.

Apesar de se perceber "mulecona" durante a infância, mencionou a vaidade com sua aparência, desde pequena. Usava roupas de adulto, brincos grandes, gostava de ler revista de moda. Inspirava-se nas tias mais novas, desejando logo crescer para poder se vestir como adulto, sem as críticas da mãe, que não a deixava usar este tipo de vestimenta e acessórios por ser nova.

Nunca foi aluna exemplar, chegando a reprovar de série, mas seus pais "tinham noção de que não tinha condição de ir prá frente. Sabiam que não gostava de estudar." A mãe a castigava, não deixando fazer as coisas que gostava como ir ao clube e nadar.

\section{A Juventude}

Aos dez anos mudou-se para outra cidade. Para Sol tudo era novidade, considerando "uma época muito boa". Aos 15 anos começou a sair à noite com amigos, tendo que voltar mais cedo que esses devido ao horário estabelecido pelos pais, uma vez que para eles "tudo tem o seu tempo”. Não entendia o real motivo do limite dado, porque "nada de errado faria".

Começou a sair com o irmão e seus amigos, e "se acha$v a$ " sendo amiga dos amigos de seu irmão. Por vezes dizia que ia dormir na casa de uma amiga para estudar, mas saía para "as baladas". Expressou de maneira saudosista: “Que época boa que não volta mais!”.

\section{A Adultez}

Na época que fez o cursinho "só tinha o interesse em festar". Mencionou que, de sua turma, ninguém passou no vestibular. Estava ansiosa para se mudar para a outra cidade onde faria mais um ano de cursinho e prestaria o vestibular novamente. Justifica por assim sair das vistas dos pais e ter sua liberdade.
Como seu intuito era sair com amigos, sem compromissos sérios, começou a namorar somente aos 20 anos com um rapaz que a "fazia meio de boba", pois como tinha que retornar cedo para casa, ele voltava "às baladas depois que me deixava em casa”. Aos sábados a preteria em função do jogo de futebol com amigos. Com a mãe do namorado tinha uma boa ligação, sendo cúmplices por esta também não aceitar as atitudes do filho e torcer pelo namoro. Terminaram quando Sol mudou-se para a cidade que faria o cursinho. Atualmente são amigos.

Na nova cidade estudava e festava, "uma nova experiência de vida, sem pai e mãe para encher o saco. Saía e não tinha hora para voltar". Após um ano de faculdade conheceu seu atual marido. Diz ter sido "amor à primeira vista" e sempre achou que seria com ele que iria se casar. "Sempre gostei dele". Naquela época ficavam juntos esporadicamente, pois ele "nada queria comigo, só queria festar".

Arrumou um namorado que "era meu oposto, não gostava de festar, era estudioso, bonzinho, meus pais o amavam”, mas Sol não. Sente que se acomodou no namoro, intuindo ser porque a família gostava dele.

Durante a faculdade "festava muito... curtia muito... Foram dois anos de festa, festa, festa, resultado: reprovei! Como estava namorando e tinha que estudar, dei uma parada com as festas". No último ano da faculdade voltou a "festar", mas o namorado não gostava, "ele tirava o telefone do gancho, me proibia de sair. Uma amiga que morava comigo falava que eu era doida...”. Terminou depois de um tempo que retornou à casa dos pais.

Namorou outro rapaz que os pais não aceitaram, "eu tinha que pagar tudo pra ele, emprestar-lhe dinheiro. Ele me fazia de tonta, apesar de gostar ainda dele. Acho que queria ajudá-lo". Ele terminou com ela quando arrumou outra namorada. Com o tempo "fui enxergando quem ele era”.

Após se formar, o pai não quis que trabalhasse, mas que fizesse um estágio. Assim o fez e recebia uma mesada "gorda" do pai. Ficou um tempo sem namorar, até quando o seu antigo amor à primeira vista ligou. Conversaram pelo telefone por umas três vezes durante um mês e resolveram se casar neste ínterim. "Meus pais sabiam que sempre gostei dele", mas ficaram receosos, uma vez que para casar teria que se mudar para a cidade dele. $\mathrm{O}$ atual marido, na época ligou para os pais justificando suas reais intenções com o casamento. Os pais conversaram com os pais dele para se certificarem. Como seus pais nunca aceitaram que fossem morar junto, tiveram que se casar formalmente. Sol conheceu os sogros uma semana antes do casamento e o marido, os pais de Sol, cinco dias antes.

Mencionou nunca ter se arrependido dessa decisão, pois disse que sempre gostou dele. Os pais não acreditavam que poderia dar certo. Para estes, Sol tinha tudo em casa e a mudança seria radical. Atualmente: 
“[...] meus pais amam meu marido. Minha mãe tratava bem o namorado da minha irmã e passou a tratar da mesma maneira meu marido. Ela não tem meio termo, gosta ou não gosta. A maneira como ela trata as pessoas é o parâmetro para saber se gosta ou não. Ela não faz questão de agradar, mas quando gosta faz de tudo!"

Casou-se, gosta do marido, "ele é uma ótima pessoa", dá o respaldo financeiro, mas não como os pais. Ele acredita que ela pode fazer várias coisas sozinha, sem depender dele. No início teve dificuldades porque não conseguia trabalhar na sua área. Disse não ter nascido para fazer serviços domésticos. No $1^{0}$ ano de casada fez curso de inglês, mas estava sem dinheiro. Não conseguindo serviço em sua área, foi trabalhar em uma franquia de comida. "O primeiro dia foi a morte. Tendo diploma superior, estava eu ali servindo as pessoas".

Este foi seu primeiro trabalho depois de casada, em cujo ambiente de trabalho, sentia-se todo o momento controlada, por haver câmeras e qualquer suspeita de que os funcionários façam algo errado são chamados à atenção, correndo o risco de demissão.

Após alguns meses nessa empresa, Sol começa a desenvolver os pensamentos obsessivos de que estava fazendo alguma coisa errada e de que poderia prejudicar alguém, bem como os comportamentos relacionados ao excesso de limpeza e verificação exagerada e repetitiva dos ambientes e de suas ações para com os outros.

Mencionou que a vida de casada sempre foi uma rotina, mas tem que acompanhar o marido. Na adolescência, os pais bancavam tudo e agora tem que correr atrás.

Há dois meses, já em psicoterapia, Sol foi demitida desse emprego, pela armadilha de ter seguido instruções de sua chefia superior que foram contra as normas da empresa. Tal atitude embasada no medo de colocar limites a tal instrução e ser demitida, não garantiu sua permanência no emprego, desprotegendo-a, quando os superiores descobriram a transgressão das normas.

Ao comunicar seus pais que fora demitida, ainda "tive que ouvir de minha mãe a pergunta sobre o que eu tinha feito de errado e que estava com vergonha de mim!”. Ficou alguns dias desempregada, e conseguiu emprego em outra lanchonete onde se encontra trabalhando até o momento.

Podemos observar, através do sucinto relato da história de Sol, que não há como não considerar que a mesma apresenta um quadro nosológico de TOC. No entanto, através deste quadro, Sol nos anuncia como lida com a contradição entre sua responsabilidade e o julgamento do outro, que a coloca em cheque. Através dos comportamentos obsessivo-compulsivos parece mostrar como vivencia a angustiante batalha entre as suas reais ações, como por exemplo, a de que não ter feito mal a alguém, ou mesmo ter apagado a luz e a dúvida sobre estas.
Experienciando o TOC como se fosse duas pessoas numa só, uma ré e a outra o juiz, podemos chegar a um psicodiagnóstico que descreve uma pessoa, no momento, tendo a sua existência absorvida por este conflito, mas que busca ansiosamente dar fim nesta batalha, só que, por não ter apropriado seu projeto de Ser, não sabe a quem entregará o troféu de vencedor: se ao réu ou ao juiz. Portanto, o projeto terapêutico engendra o caminho para que ambos saiam de cena, dando lugar a uma síntese em que a avaliação de seus atos seja balizada a partir de seu próprio crivo e não alienada em projetos alheios, ou seja, que se torne "sujeito de seu ser" (Schneider, 2011, p. 271).

Destarte, até que tal intento seja alcançado, veremos a seguir, "as variáveis fundamentais na constituição dos impasses psicológicos [de Sol], compreendidos no horizonte da sua personalidade" (ibdem, p. 270), ou seja, como Sol se sabe, a partir de sua dinâmica psicológica construída através do diálogo que trava com o mundo.

\section{$2^{\circ}$ momento: Elaboração da Problemática - Possibi- litando a Compreensão Terapêutica}

O homem sartreano sendo corpo/consciência (emsi-para-si) é um homem em relação: "entre consciência e corpo, relação com o mundo que o cerca, relação com a exterioridade" (Schneider, 2011, p. 213). Como ser-no-mundo, sua intencionalidade está voltada sempre para o exterior. Assim, sua consciência estabelece relação com a materialidade. Nascemos num mundo já posto, que se nos apresenta com uma história dada e com condições materiais pré-existentes ao nosso nascimento.

Sol nasceu na metade da década de 70, no berço de uma família católica, com padrões rígidos de criação, os quais se confrontavam com um Zeitgeist $t^{5}$ de transição de valores culturais e econômicos. O Brasil, apesar de ainda estar sob a ditadura militar do então Presidente Ernesto Geisel, vivenciava o auge do movimento feminista, a eclosão dos movimentos musicais de rock in roll, do início da era Dancing Days, com o surgimento das discotecas e do movimento punk. Na moda as vestimentas e adereços aparecem com muitas cores e brilhos. A calça boca de sino, sapato plataforma, saltos altos e finos com meia lurex, ou seja, a moda Psicodélica foi de encontro a tudo que era tradicional. Para sobreviver a esse movimento de contracultura, os padrões das famílias tradicionais necessitavam enrijecer.

Quanto à condição financeira estável da família, poderia ser beneficiada também pelo período de crescimento econômico que o Brasil passava. Sol então, ao nascer e durante parte de sua infância, se deparou com uma exterioridade que mostrava um contexto de abertura de-

5 Espírito da época. 
mocrática, mas no familiar, em contraponto, ocorria um recrudescimento dos padrões de educação.

Como toda relação do homem é dialética (interiorização do exterior e exteriorização do interior), Sol se apropriou da segurança financeira de maneira conflitante: se por um lado tinha a segurança financeira oferecida pelo pai, por outro se sentia culpada por depender deste, posto que as possibilidades dadas para usufruir o que desejava eram também colocadas com cobranças.

No tocante às regras impostas em sua criação, não via sentido em algumas, inclusive a de ter que sair das festas mais cedo que seus amigos. Sol se sentia culpada por poder fazer coisas erradas aos olhos dos pais, sem saber o fundamento deste prejulgamento.

O projeto dos pais com relação ao filho ideal foi exteriorizado por estes através de ações que Sol deveria desempenhar: estudar, fazer faculdade, estagiar após se formar ao invés de trabalhar, chegar mais cedo em casa, usar roupas adequadas para sua idade, ter amigos como seu irmão, namorar um rapaz com o perfil traçado pela família, enfim, tal projeto foi interiorizado por Sol como aquele que limitava sua espontaneidade, sendo assim, vivenciar suas escolhas sem julgamentos, somente longe dos pais. Prazer e diversão somente nesta última situação, porém, continuava financiada por eles. O prazer e as obrigações são entendidos por Sol de maneira dicotômica, sem haver um diálogo entre eles, somente na base financeira.

A relação com o corpo, outra condição constitutiva da existência, faz-se importante mencionar. O corpo não deve ser entendido de maneira cartesiana, separado da consciência. Ambos integram-se ${ }^{6}$, totalizando o Ser. É por meio do corpo que mediamos nossa relação com o mundo.

Schneider (2011) menciona que Van Den Berg (1981) sustenta duas maneiras de o sujeito relacionar-se com o corpo: o corpo como ser-para-o-outro e o corpo que sou (corpo ser-para-si). No primeiro, o corpo é visto de fora, é o corpo alienado ao ponto de vista dos outros, é o corpo abstrato, e o segundo, o corpo concreto, aquele que vivencio enquanto espontaneidade por ser meu instrumento no mundo e meta de minhas ações.

A maneira como Sol fala de seu corpo, mostra-nos interiorizá-lo a partir do olhar do outro. Sentia-se gordinha e feia na infância, tendo como fundamento a crença de que os meninos não gostavam dela. Atualmente cuida de sua aparência, faz regime, pois ainda percebe seu corpo de maneira distorcida, sendo sempre mais avantajado do que é. No entanto, interessante compreender que em alguns comportamentos relacionados ao Toc, o corpo sujo é apropriado como o corpo ser-para-si.

A relação que travamos com a temporalidade também deve ser visada. Sabemos que o existencialismo compreende que os acontecimentos históricos são criados

6 Corpo/Consciência $=$ Somos . num movimento do futuro para o passado, condição da consciência intencional projetar-se no futuro, ascender o passado e realizar as escolhas no presente, sintetizando assim, passado, presente e futuro. No entanto, essa temporalização real, antropológica nem sempre é experimentada desta maneira pelo sujeito. Este geralmente entende o passado como determinante de seu presente e futuro, tornando assim, uma temporalização aparente (Schneider, 2011).

Sol teve seu futuro praticamente delineado pela sua criação. Como deveria agir, ter e ser fora predefinido pelos projetos dos pais, contudo, não a estimularam a arriscar e aprender, do seu jeito e no seu tempo, o como fazer. Aprendeu que devia ser responsável no que faz, mas o futuro tornou-se ameaçador, ansiógeno, quando deve criar saídas, haja vista que, para Sol, no passado estas eram criadas por outro. Diante o nada do vazio, paralisa-se, dorme, tem preguiça, e assim age para recusar o risco. Da mesma maneira ansiógena lida com o pensamento de ter feito algum mal aos outros ou ter deixado algo por fazer e que pode trazer algum dano, na verdade, não ao outro, mas a ela. No caso do Toc, precisa assegurar-se, através do outro, que seu futuro não está ameaçado, quando lhe pergunta se fez algo de errado.

Só podemos nos conhecer através do outro. Assim a criação do nosso Eu perpassa antes o olhar alheio. Na sua relação com o outro, Sol o percebe como seu juiz, seu inferno. Sendo o outro quem define os caminhos a serem trilhados no percurso das obrigações e compromissos, tornou-se dependente desses para não correr risco, mas, paradoxalmente, os outros também são os que limitam sua liberdade relacionada ao prazer e diversão. Estabelece então, uma relação conflituosa com os outros: estes são interiorizados como protetores-castradores e não como limitadores-possibilitadores.

De acordo com a maneira como trava a relação com o outro, a sua com o TOC se dá fundamentada através de um Eu dividido. Vivencia um estranhamento com relação aos seus pensamentos sobre fazer mal a alguém. Apesar de ter os pensamentos obsessivos, sabe que não fez e que não fará mal se não quiser. O mesmo ocorre com os comportamentos de verificação dos ambientes, de lavar as mãos e de questionar as pessoas se a fez algum mal. Tem a compulsão, faz, mas sabe que não há necessidade.

Tal vivência pode ocorrer porque ter conhecimento de algo não significa ter consciência reflexiva de. O Eu só surge diante a consciência reflexiva, uma vez que somente ela posiciona o Eu no mundo, sendo assim, podemos desvelar o projeto de Ser de Sol, através de suas ações, as quais não mostram uma consciência reflexiva do Eu que, por sua vez, de maneira irreflexiva, se sabe sendo. 


\section{Desvelando o Projeto de Ser: o Eu Alienado}

Conforme podemos compreender a dinâmica psicológica de Sol, esta por se saber sendo impotente, incapaz, limitada intelectualmente, medrosa, preguiçosa, feia, má, rejeitada, mas responsável: (1) projeta ser uma pessoa com segurança financeira, mas financiada pelo Outro (no caso atual, o marido); (2) por meio do trabalho busca ser reconhecida pela sua honestidade e responsabilidade, não suportando dúvidas sobre sua idoneidade; (3) idealiza ser amada como uma boa filha. Pela culpa em omitir seus erros e fracassos dos pais, dá satisfações de sua vida para eles, o que ratifica seu sentimento de rejeição quando eles a julgam e; (4) mantém o corpo sob excessivo cuidado (corpo abstrato) para ser bonita para o Outro. Mas, por estar magra, continua recebendo críticas.

Vemos aí um Projeto de Ser-para-o-outro, cujo Eu fracassado foi interiorizado pelo olhar do outro. Sem passar pelo seu senso crítico, a fim de poder escolher com mais reflexividade sobre o que criaram para ela, Sol aceitou e assentou este Eu. Mesmo que apresente em alguns de seus comportamentos uma tentativa de libertação deste, o faz com culpa, expondo-se e interiorizando as críticas, uma vez que a maneira como tenta se livrar deste fardo, não é de maneira transcendente, mas em oposição, aparecendo para o outro como um confronto que também 0 ameaça.

Diante esta compreensão, o trabalho com Sol foi encaminhado para que a mesma pudesse apropriar-se desse Eu que se sabe sendo, construído no modo como estabeleceu relação com a realidade. Sem a consciência reflexiva deste, impossível responsabilizar-se como também construtora do mesmo e assim poder redimensionar seu Ser.

Veremos a seguir como ocorreu este processo de redimensionamento até o momento.

\section{Redimensionando o Projeto de Ser}

\section{Reflexão Espontânea ou Cúmplice}

Como coloca Schneider (2002, p. 168):

Um homem escolhe-se em uma dada estrutura de escolha; a escolha não é, portanto, gratuita, determinada unicamente por seu desejo de sujeito, mas é uma escolha a partir das possibilidades que se lhe apresentam e frente às quais ele não pode deixar de escolher.

A estrutura de escolha com que Sol se deparou durante sua infância, foi a de uma criança que não correspondeu às expectativas do perfil de filha já desenhado pelos seus pais antes mesmo dela nascer. De uma maneira irreflexiva, que posiciona as coisas e pessoas no mundo, mas ainda não posicional do Eu (Sartre, 1965; Bertolino et al, 1998 citados por Schneider, 2002, p. 339), Sol reflete que os pais criaram para ela o projeto de filha perfeita, mas paradoxalmente, para atingirem o projeto de serem pais perfeitos, uma vez que para serem pais bons, precisam ter filhos problemáticos. "Meus pais me deixaram dependente, impotentes, limitada ao traçarem meus caminhos, buscarem solucionar meus problemas, me bancando financeiramente."

Colocou que sua educação foi direcionada para a obediência, o que gera passividade e infantilidade. Não a deixaram arriscar e assumir as consequências de suas escolhas, "até porque o que eu escolheria poderia ir contra os valores deles. Só que me criticam também por não arriscar. Parece não haver saída na relação com eles, ou sou do jeito que eles querem ou não tenho valor!".

No tocante as suas relações amorosas, acredita que para seu pai nenhum homem seria tão bom para ela quanto ele, mas que atualmente conseguem aceitar seu marido e ver que este é bom. Até aqui Sol posiciona o Outro no mundo, mas é necessário que realize uma reflexão crítica, posicionando seu Eu para si.

\section{Reflexão Crítica}

Intervindo durante o processo psicoterapêutico, de maneira a mostrar-lhe suas escolhas diante esse mundo que se deparou, até o momento, Sol conseguiu apropriarse de algumas escolhas que faz, fundamentadas em seu Projeto de Ser, questionando-as e redimensionando-as, a saber: (1) no tocante às satisfações que dá aos seus pais sobre seus erros e fracassos, atualmente têm consciência de que é uma mulher adulta e casada, que não precisa dar-lhes essa obediência, mas que para isso, precisa ser independente financeiramente, não emprestando mais dinheiro deles. "Meu pai não aceita que eu o pague, diz que estou com pouco dinheiro, mas assim eu crio uma dívida afetiva"; (2) quanto as suas relações com o outro, inclusive no trabalho, não permite mais que a hierarquia seja justificativa para tratarem-na mal. "Não é porque é meu superior que tem o direito de falar do jeito que fala. Que aponte meus erros, mas não precisa ser sem educação" e; (3) sobre o TOC, coloca que está melhorando. "Consigo não voltar atrás para verificar se está tudo desligado em casa. Se eu tenho a certeza que desliguei, saio, mesmo com o coração apertado. Estou duvidando menos do que faço". Atualmente Sol toma um comprimido do Lexapro, três vezes na semana.

Em busca desta elucidação do Projeto de Ser, a psicoterapia encaminha-se com o propósito de ajudar Sol a conscientizar-se de que nossa existência não é determinada, mas sim construída. Os resultados da nossa relação com o mundo escrevem a nossa história, portanto, podemos também escrevê-la de maneira não alienada. 


\section{Um Ser em Construção: Considerações Finais}

Diante todo o exposto, acompanhamos, mesmo que de maneira breve, a história de uma mulher sufocada por um projeto de ser construído mesmo antes de sua existência.

A maneira dicotômica como interiorizou o mundo, oportunizou vivências contraditórias entre perfeição x imperfeição, certo x errado, dependência x independência, maturidade x imaturidade, alienação x liberdade.

Filha de pais cujo projeto de filhos perfeitos é definido por aquele que não dá trabalho, mas orgulho, Sol fracassa desde seu nascimento, não se mostrando um bebê "bonzinho". Ao chorar frequentemente, sem que o motivo fosse descoberto, nem pelos especialistas, começou a tirar a tranquilidade dos pais no sucesso de terem uma filha que correspondesse suas expectativas.

Frustrando o projeto inicial que fizeram para ela, opostamente, os pais interiorizaram a imagem da filha imperfeita. Quiçá, a mãe ao contar-lhe o episódio de sua história sobre seu choro, Sol tenha percebido a decepção em sua fala e o quanto dera trabalho para os pais e os deixara impotente. Perceber-se irreflexivamente, como uma criança problemática, por não fazer nada certo segundo os pais, fez sentir-se o patinho feio da família e não amada por eles.

Destarte, no decorrer de sua infância e adolescência, os comportamentos da filha problemática passam a ser foco de controle dos pais. Normas de conduta compõem a cartilha da boa educação de Sol e a culpa, o instrumento de controle e manipulação. Sufocada pelos limites impostos à sua liberdade, Sol busca experienciá-la de maneira opositiva ao projeto dos pais. Mas nessa busca por ações orientadas somente pela liberdade ontológica, Sol não tinha consciência de que suas escolhas ratificavam o Ser diferente e problemático definido por eles. A cada ação diferente do que se esperava dela, um olhar que a julgava e punia pelo seu fracasso em ser um modelo a ser seguido. Foi através das repetições dos empreendimentos de ambos os lados, que a relação dependente entre Sol e seus pais se sintetizou.

A tese dos pais, que compreendia os seus padrões de conduta, foi um dos focos a ser combatido por Sol, mas ao buscar transcendê-la, o fazia negando o ser em situação, não compreendendo que:

O homem é condenado à liberdade, numa perspectiva ontológica, pois não pode deixar de escolher; no sentido antropológico, contudo, ele nunca é inteiramente livre, pois como diz Sartre na Questão de Método, "a alienação está no ápice e na base”, quer dizer, o homem nunca será inteiramente desalienado, já que sua condição de ser-com-os-outros o coloca sempre em poder dos demais [grifo da autora] (Schneider, 2002, p. 168).

Assim, ao direcionar a possibilidade da experiência livre somente aos contextos que compreendem diversão e prazer, excluindo aqueles relacionados aos compromissos e obrigações, Sol paradoxalmente, enquanto festava, perdia a admiração dos pais, projeto também a ser conquistado por ela. Pelo lado dos pais, que a viam incapaz de agir com responsabilidade e ter sucesso em seus empreendimentos, cobriam financeiramente os prejuízos causados.

Mesmo tendo a imagem de Sol como uma pessoa imatura e incapaz, os pais, ao buscarem consertar financeiramente suas ações inconsequentes, oportunizando a Sol e aos outros dois filhos as condições objetivas para que nada os faltassem, e indicando o melhor caminho a ser seguido, mostram o projeto de Ser pais a ser perseguido e mantido, circunscrito num projeto social.

Vemos até aqui a trama da história de Sol tecida pela sua e por várias outras mãos, bem como ajudava a escrever também a história dos pais, da família e da sociedade, tal como coloca Schneider (2002, p. 120):

O homem faz a história, ao mesmo tempo em que é feito por ela. Eis o processo dialético que engendra a realidade sócio-cultural. No entanto, é preciso assinalar que a história não está em meu poder, ela me escapa.

Se por um lado tinha como ponto de referência os modelos impostos para se debater, por outro Sol não aprendera, nem foi ensinada a criar saídas alternativas. Padrões predefinidos e caminhos orientados ajudaram Sol a estabelecer seu ponto de referência no mundo, inclusive seu Eu real fora baseado empiricamente na oposição do ideal imposto, e afetivamente na ausência do reconhecimento de sua capacidade. Um Eu paradoxalmente construído através das faltas: dos impedimentos de se expressar como desejava, da incapacidade de obter sucesso, do afeto que envolve a admiração. Foi assim que Sol conhecia seu Eu: impotente, limitado, incapaz, fracassado, errado, acomodado, dependente dos pais, mas não admirado e não amado.

Com relação ao TOC, Sol o experiencia como um evento ahistórico, singular, desconectado de uma possível construção com o social. Compreendendo como um evento isolado, de sua única responsabilidade e que reforça seu projeto de Ser uma pessoa que faz coisas erradas, Sol busca em sua família de origem o apoio de sua cura.

Mais uma vez a família é acionada para proteger as ações de Sol, agora diante algo inusitado e desconhecido, que os deixam impotentes, como sempre devem ter se sentido na criação desta. Como na época que chorava quando era bebê, a família procura ajuda de um especialista, no caso o psicoterapeuta.

Partindo da história de Sol, de seu projeto de Ser, o trabalho realizado em psicoterapia visa, de uma maneira geral, a ajudá-la a apropriar-se do projeto fundamental que criou para si, buscando altera-lo ou não, mas a partir de seu próprio crivo. 
Os caminhos percorridos para a conquista deste objetivo mais amplo envolvem alguns outros mais específicos, tais como: (1) a compreensão de quais valores embutidos no projeto dos pais, fundados numa forte moral religiosa, de uma família patriarcal com certo tom de preceitos machistas, fazem sentido para ela, como aqueles que deseja descartar; (2) o reconhecimento da diferença entre as preocupações e medos fundados em situações reais, objetivas e aquelas apoiadas em situações somente imaginárias e subjetivas; (3) a compreensão do nexo de suas ações que se enquadram no diagnóstico tradicional de TOC, com seu Projeto de ser; (4) a consciência de que precisará criar saídas alternativas para situações em sua vida, ao invés de esperá-las prontas, conhecendo seus valores como ponto de apoio para essas escolhas, e que isso também envolvem riscos, mas que mostrará através de ações mais maduras e protetoras de si, por estarem situadas na síntese de suas limitações e possibilidades, podendo assim responsabilizar-se mais facilmente por elas.

Observo que nos caminhos da psicoterapia que estamos construindo juntas, a liberdade que antes era vivida por Sol como se fosse errada, chegando a considerar-se "muito doida", hoje é compreendida como uma "loucura com responsabilidade”, uma vez que também em suas diversões, escolhia de maneira consciente não transgredir alguns fundamentos da moral que embasa os valores paternos, por concordar com estes.

Conseguiu também perceber, que o estranhamento que sentia com relação aos pensamentos obsessivos era o mesmo que sentia diante a falta de sentido de algumas regras impostas pelos pais, como, por exemplo, ter que chegar às $22 \mathrm{~h}$ em casa, enquanto suas amigas poderiam continuar se divertindo, sabendo que ela não iria fazer nada que abonasse sua conduta, mas mesmo assim julgava-se errada, como já dito anteriormente.

Por fim, reconhece agora, que na vida há também limites e regras, obrigações e compromissos, e a maneira como deve lidar com elas requer sintetiza-las as suas possibilidades. E assim, vamos construindo nossos encontros psicoterapêuticos.

\section{Referências}

Cahet, H.J.P. (2008). Sartre: aspectos de noção de consciência. Dissertação de Mestrado, Universidade Federal de Santa Catarina, Florianópolis, Santa Catarina.

Husserl, E. (1988). Elementos de uma elucidação fenomenológica do conhecimento. In HUSSERL, E. Investigações lógicas: sexta investigação: elementos de uma elucidação fenomenológica do conhecimento. São Paulo: Nova Cultural. (publicado originalmente em 1901).

Sartre, J-P. (1997). O Ser e o Nada. Ensaios de ontologia fenomenológica. Rio de Janeiro: Vozes. (Publicado originalmente em 1943).

Sartre, J-P. (2002). Crítica da razão dialética. Rio de janeiro: DP\&A. (Publicado originalmente em 1960).

Schneider, D. R. (2002). Novas Perspectivas para a Psicologia Clínica - um estudo a partir da obra "Saint Genet: comédien et martyr" de Jean-Paul Sartre. Tese de Doutorado, Pontifícia Universidade Católica de São Paulo, São Paulo.

Schneider, D. R. (2011). Sartre e a psicologia clínica. Edufsc: Florianópolis, SC.

Sylvia Mara Pires de Freitas - Psicóloga. Mestre em Psicologia Social e da Personalidade (PUC/RS). Especialista em Psicologia do Trabalho (CEUCEL/RJ). Formação em Psicologia Clínica na abordagem existencial (NPV/RJ). Docente dos cursos de Psicologia da Universidade Estadual de Maringá (UEM/PR) e da Universidade Paranaense (UNIPAR/PR). Endereço: Av. Colombo, 5.790 - Bloco 118 (DPI). Jardim Universitário. Maringá. Paraná. CEP 87.020-900. E-mail: sylviamara@gmail.com 